\title{
Reticular Fiber
}

National Cancer Institute

\section{Source}

National Cancer Institute. Reticular Fiber. NCI Thesaurus. Code C33468.

Proteinaceous fibrils found in connective tissue that are comprised of type III collagen and form a mesh that can support soft tissue structure. 